\title{
Plant economy in the westernmost territory of the Roman state through waste: the wet site of O Areal (Vigo, Spain)
}

\author{
Andrés Teira-Brión
}

Universidade de Santiago de Compostela. Departamento de Historia, Praza da Universidade 1, 15782, Santiago de Compostela, Spain. andres.teira.brion@usc.es

\section{https://orcid.org/0000-0001-8997-1425}

\begin{abstract}
The Roman economy of the Iberian Peninsula has habitually been characterised in terms of prestige goods and economic activities such as trade, mining and metallurgy. The analysis of plant-based foods -less prestigious but more essential in everyday life- has commonly been marginalised in state-of-the-art reviews. The $\mathrm{O}$ Areal saltworks is exceptional in terms of the large number of organic materials it preserves, and the excellent state of that preservation. After its abandonment (end of the 3rd/4th century AD), the saltworks was briefly used as a dumping ground for the surrounding area. The site's archaeobotanical remains, preserved under anoxic, waterlogged conditions, consist of the building materials used at the saltworks, tools and other artefacts, organic objects employed in activities such as fishing, and refuse. The assemblage suggests a wide diversity of species to have been introduced into northwestern Iberia during the Roman Period, including the mulberry, peach, fig, plum, grapevine, and melon. The notable presence of other edible fruit species that normally grew wild during this period, such as chestnut, walnut, stone pine, and cherry trees, might be related to the start of their cultivation.
\end{abstract}

Keywords: waterlogged preservation; millet; arboriculture; crop expansion; urban area; Iberian Peninsula.

Funding: This work was funded by the Xunta de Galicia through the Consellería de Cultura e Turismo (2008-CP068 and 2009-CP078) and the Dirección Xeral de Patrimonio Cultural (2009-CP015).

Conflicts of interest/Competing interests: None to declare.

Availability of data and material: Not applicable.

Code availability: Not applicable. 


\section{Introduction}

The representativeness of plants in the archaeobotanical record is conditioned by many factors, including their selection and transformation by humans, the environmental and edaphic conditions where the remains were deposited, their alteration by biotic factors, the stability of the deposition conditions, and how such materials were recovered and stored during archaeological excavations. Plant materials for which fire is involved at some point in their gathering, processing, storage, consumption or discarding, are commonly much better represented than those that are consumed fresh, require much processing, or that rapidly perish. Although the Iberian Peninsula has a diversity of climatic conditions, the seeds and fruits represented in the Roman archaeological record are usually found in the form of charred remains (Peña-Chocarro et al. 2019). Waterlogged sites have received relatively little attention (Figure 1) but could help complement our archaeobotanical knowledge. Such sites include the saltworks of O Areal (Vigo, Spain) (Teira Brión 2010), the healing spa of Aquae Flaviae (Chaves, Portugal) (Vaz et al. 2016), the well of Idanha-a-Velha (Portugal) (Almeida and Ferreira 1967) and the structures of the port of Irun (Euskadi, Spain) (Carrión 2012; PeñaChocarro and Zapata 1997; Peña-Chocarro and Zapata 2005; Urteaga Artigas 2003; Urteaga Artigas and Gereñu Urzelai 2003).

Constantly submerged, waterlogged sediments facilitate the preservation of organic matter, including that used to make objects. The oxygen turnover is slow, generating conditions unsuitable for microbial growth, consequently reducing the rate of degradation (Bleicher and Schubert 2015). This allows for the better preservation of leaves, pericarps, endocarps, woody materials and fibres commonly broken down at dry sites, although it does not favour the preservation of cereal caryopses (their recovery from wet sites is unusual). The organic remains found at wet sites can, of course, have been affected by transport or re-deposition (Antolín et al. 2017a), or changes in the physicochemical conditions and relative humidity of the surrounding water and sediment (Martín Seijo et al. 2010). 


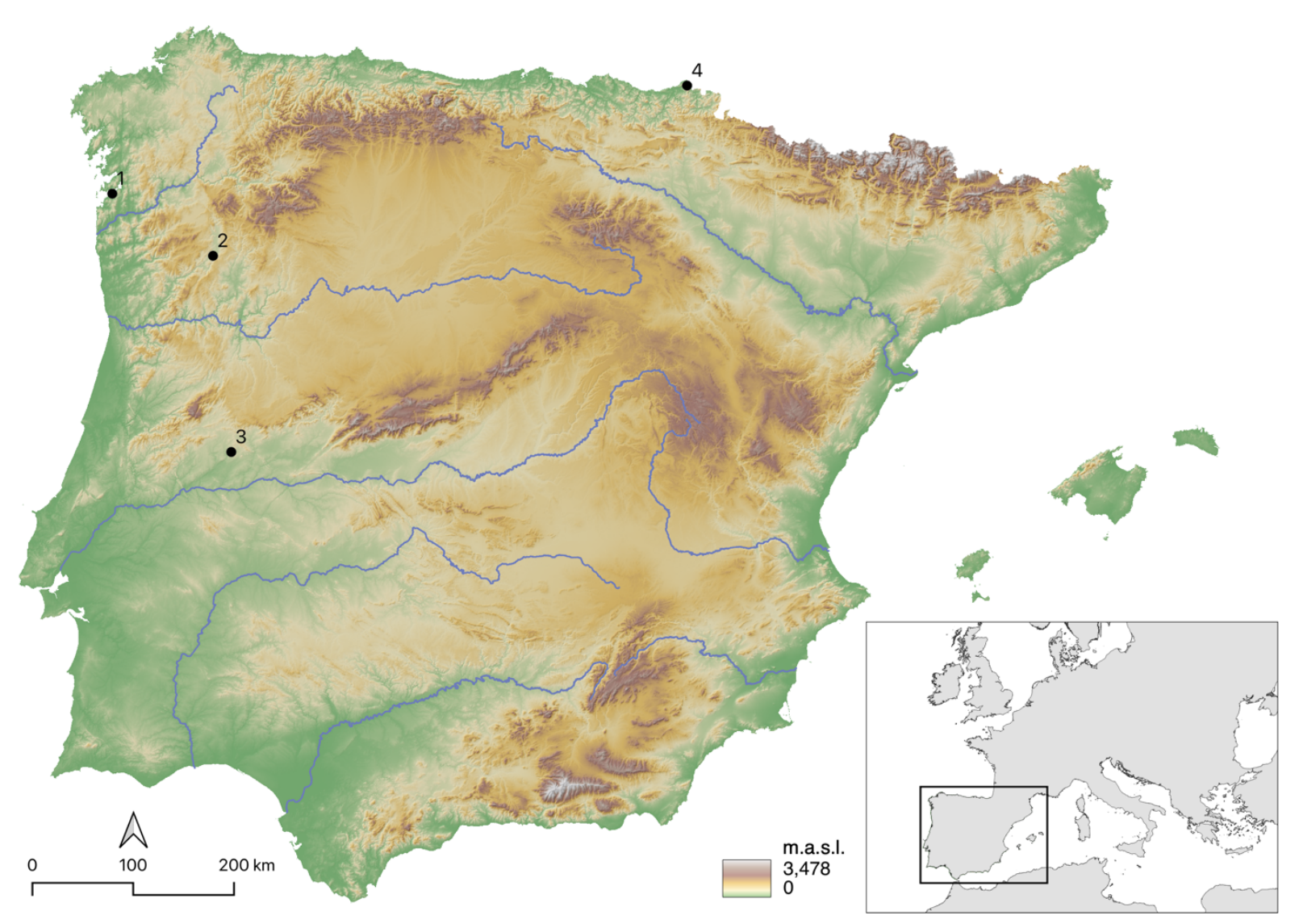

Figure 1 Location of waterlogged Roman sites in the Iberian Peninsula: 1) O Areal, 2) Aquae Flaviae, 3) Idanhaa-Velha, and 4) Irun.

\subsection{Archaeological background}

The conquest of the Iberian Peninsula by the Roman State (218-19 B.C.) brought about a social and economic rupture. In agriculture, its impact can be observed at several scales: a) the introduction of new crops (Peña-Chocarro et al. 2019); b) new forms of land organisation and exploitation (Brun 2004; Lewit 2020); c) changes in the social structure of labour (Alfaro Giner 2010; Rodríguez Neila et al. 1999), and d) the integration of agricultural production within more global trade systems (Carreras and Morais 2012; Martín i Oliveras et al. 2017; RubioCampillo et al. 2018). The arrival of new fruit-tree species from the Mediterranean began during the 1st millennium B.C., thanks to the establishment of Phoenician and Greek colonies on the Mediterranean and southern Atlantic coasts (Buxó 2008; Pérez-Jordà et al. 2021). It was during this time that pomegranate (Punica granatum), almond (Prunus dulcis), and fig (Ficus carica) trees arrived, along with the grapevine (Vitis vinifera subsp. vinifera) and melon (Cucumis melo) (Pérez-Jordá et al. 2017). Although these civilisations established commercial exchanges and intense cultural contacts, arboriculture did not fully spread throughout Iberia during the Iron Age (cf. Pérez-Jordà et al. 2021). Certainly, it was not until the Roman conquest 
that new food crops (possibly including rye) and ornamental species (Cupressus sempervirens) were introduced and the interior and north of the Peninsula became home to plants cultivated in the Mediterranean area (vines, figs, olives, peaches, melons) (Alonso Martínez 2005; PeñaChocarro et al. 2019; Teira Brión and Rey Castiñeira 2021; Tereso et al. 2020; Vaz et al. 2016).

It is not easy to trace the biographies of many of these new crops in the archaeobotanical literature. The arrival of Mediterranean peoples could have driven the development of innovative agricultural practices and led to the domestication of certain local species, new domestic varieties, and perhaps even allowed for genetic exchange with wild varieties, as suggested for grapevine (Cunha et al. 2020; Freitas et al. 2021; Riaz et al. 2018). The same may have been true for other species at this time, such as chestnut (Castanea sativa), apples/pears (Pyrus/Malus), olive (Olea europaea) or sweet cherry (Prunus avium); species that frequently appear in archaeobotanical assemblages (cf. Peña-Chocarro et al. 2019) but whose remains offer little information regarding a wild or domestic origin. The context in which they are found, and their frequency, need to be taken into account in any interpretation of their presence.

Some crops, e.g., citrus fruits (Citrus medica and Citrus limon - the citron and lemon respectively) known from texts, pictorial representations and preserved seeds and fruits (ZechMatterne and Fiorentino 2017) to have been present in other parts of the Roman State, e.g., the Italian Peninsula, did not arrive in the Iberian Peninsula in Roman Period according to current data (Peña-Chocarro et al. 2019). The same is true for black pepper (Piper nigrum), bottle gourd (Lagenaria siceraria), sesame (Sesamun indicum), and rice (Oryza sativa) (Bakels and Jacomet 2003; Bosi et al. 2020; Jacomet and Vandorpe 2011; Livarda 2011; Wiethold 2003). Their absence (and that of other species) may be due, however, to a) the need for further archaeobotanical study, b) these species being associated -in very specific contexts- with poorer social classes or high-status individuals, or c) differences in the adoption of the same species within the different territories that made up the state. Knowing the reasons why crops were accepted or not in each territory allows for the economic transformations that took place, and the preferences and habits in food and drink, to be observed, bringing us closer to understanding how society changed, and to comprehending the intercultural context that laid the foundations of Roman culture in Iberia.

\subsection{Objectives}


The O Areal saltworks provides an opportunity to gain new knowledge about the use of plant species by human communities during the Roman Period in the Iberian Peninsula, complementing that made available by other archaeobotanical research lines (Peña-Chocarro et al. 2019). The site is home to an interesting assemblage of archaeobotanical remains preserved below sea level, some of which have been the subject of previous publications (Martín-Seijo 2019; Teira Brión 2010). The majority are construction structures, wooden artefacts, the seeds, and fruits etc. of cultivated and wild species, foodstuff residues, and objects made of organic (e.g., leather) and inorganic materials.

The aim of the present work is to identify the plants represented in the organic mattercontaining level that was deposited over the saltworks after it was abandoned. The results throw light on the establishment of a Roman agricultural economy in northwestern Iberia, on how urban areas may have acted centres for the expansion of new agricultural practices, on the introduction of new crops, the consumption of species present in the natural environment, the possible combined use of domestic and wild plants, and on how human activity affected the natural environment, complementing the information obtained in previous archaeobotanical research -see (Peña-Chocarro et al. 2019).

\section{The saltworks of O Areal}

Salting was a known food processing technique in the northwest of the Iberian Peninsula from at least the mid $2^{\text {nd }}$ century B.C. (González Gómez de Agüero 2013; Rodríguez Martínez et al. 2011), although it was not until the Roman Period that it became an important economic activity. Pelagic species such as the sardine (Sardina pilchardus) were commonly caught (González Gómez de Agüero 2013) to make salting and sauces (García Vargas and Bernal Casasola 2009). Salting fish, however, required a reliable supply of salt. A series of coastal saltworks (cf. Currás Refojos 2007) was thus established to extract it from sea water. The O Areal saltworks, with a surface area of around $10 \mathrm{Ha}$ (García Vargas and Martínez Maganto 2017), is one of the largest ever identified in the Roman State (Currás 2017). The structures of the saltworks extend for more than a kilometre parallel to the coastline of the present-day city of Vigo (cf Castro Carrera 2006; Castro Carrera 2007; Castro Carrera et al. 2019; César Vila 2010; Iglesias Darriba 2009; Iglesias Darriba 2010; Iglesias Darriba et al. 2017).

The construction of the saltworks was associated with the transformation and anthropization of a fluvial-marine complex with a lagoon environment that formed around 1500-1000 B.C. 
(Tallón-Armada et al. 2018). Its development may have been favoured by the beginning of the Roman Warm Period (100 B.C.-400 A.D.), characterised by a drier and warmer conditions than the previous climatic phase (Tallón-Armada et al. 2018). This, together with the stabilisation in sea level or its slight rise, may have justified the location of this type of exploitation on the Atlantic coast (Tallón-Armada et al. 2018). The archaeological levels prior to the saltworks have been radiocarbon dated to 149 cal B.C.-116 cal A.D. (2020 \pm 40 BP) (Tallón-Armada et al. 2015), and the ceramic materials they contain indicate that the first construction facies of the ponds would have taken place after 50-70 A.D. (Iglesias Darriba et al. 2017).

O Areal was a solar evaporation saltworks divided into three main areas connected by a system of channels and sluices (Castro Carrera 2007): 1) settling ponds, where brackish water was stored and decanted to remove materials in suspension; 2) evaporation ponds where the salt concentration was increased through exposure to the sun, and 3) crystallisation ponds, where the transformation into salt crystals took place. The settling ponds documented in the eastern sector are rectangular in shape and between 14.6-16.2 $\mathrm{m}$ long and 7.5 to $8.3 \mathrm{~m}$ wide (Iglesias Darriba et al. 2017). The walls, made of slabs of schist and granite, were 0.7-0.8 $\mathrm{m}$ high, indicating that the water would have been around $0.6 \mathrm{~m}$ deep (Iglesias Darriba et al. 2017). This water entered under the control of a sluice (Iglesias Darriba et al. 2017). The same sector contains several crystallisation ponds and a building that could have been used for storage (Iglesias Darriba et al. 2017). The crystallisation ponds were built on stone slabs with a clay pavement, and had small walls bordering them. A peculiarity is that these ponds were located higher than the evaporation ponds, requiring brine of variable density-depending on the degree of Baumé reached- be transported to them manually or mechanically (García Vargas and Martínez Maganto 2017; Iglesias Darriba et al. 2017). 

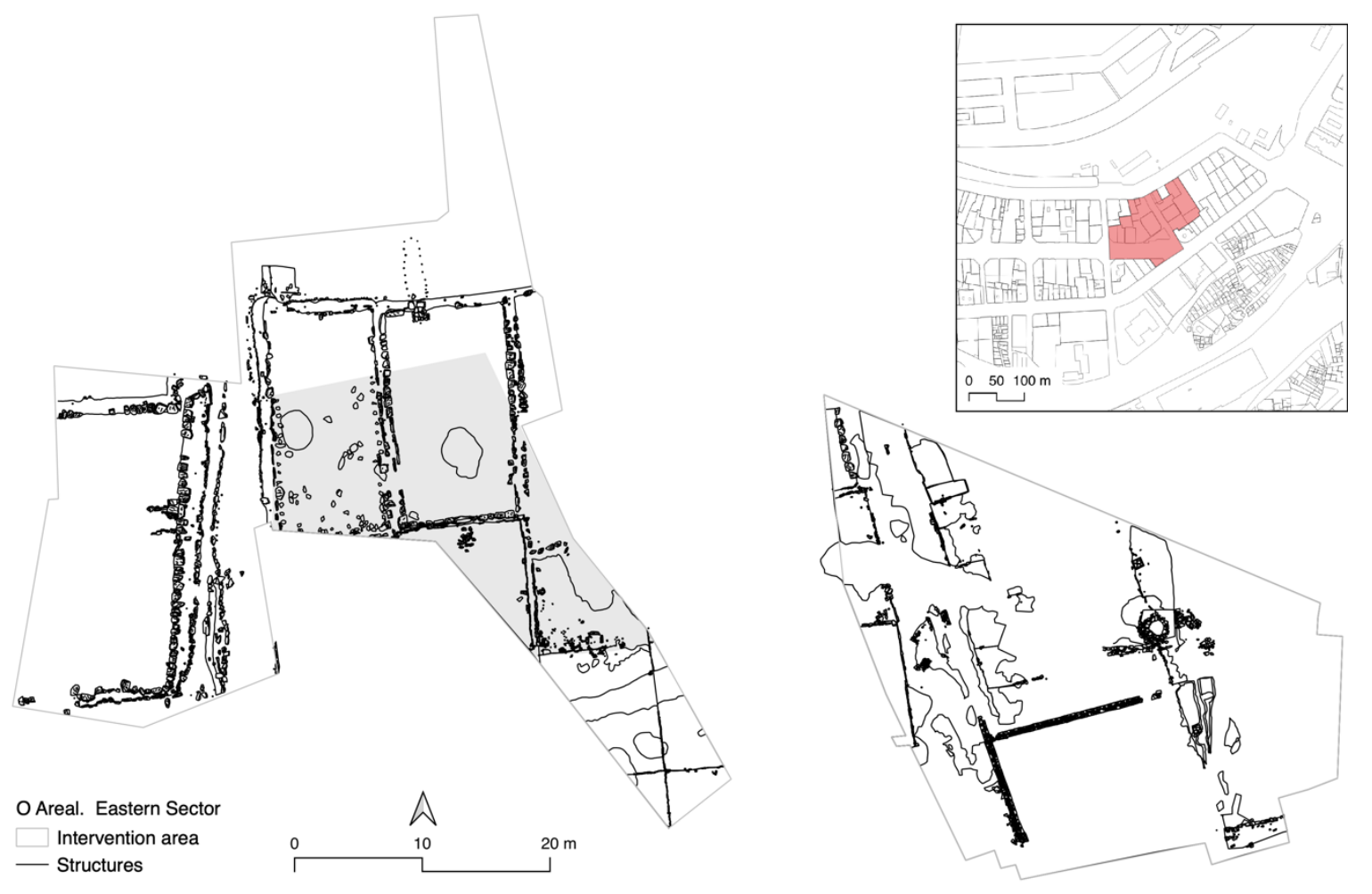

Figure 2 Evaporation and crystallisation ponds in the eastern sector of the O Areal site (Unidade de Actuación II06). Sediment around samples B2548 and B2616 was gathered from SU1049 (grey area). Re-drawn from the survey plan of M. J. Iglesias Darriba and M. Á. Sartal Lorenzo.

The increase in rainfall at the end of the 3rd century A.D. may have shortened the useful brine evaporation period (Tallón-Armada et al. 2015), perhaps leading to the end of the saltworks' activity in the 4th century A.D. However, the lack of a general context for saltworking in northwestern Iberia renders it impossible to know whether salt production was abandoned because of changes in the activity of the fish-salting factories it served. The zenith of the latter activity was reached during the Early Roman Empire; in the 3rd-4th A.D. centuries it declined and many salting installations disappeared, a crisis that affected the entire Iberian Peninsula (cf. Corrales Aguilar 2011-2012; Expósito Álvarez 2011).

The abandonment of the saltworks is marked in the archaeological record by levels of stones resulting from the collapse of the surrounding structures, on which a level with a high content of silt and clay formed (Tallón-Armada et al. 2018), plus an intercalated sandy deposit representative of a coastal-marine environment that accumulated a large amount of organic matter (Tallón-Armada et al. 2015). The plant remains within it have been interpreted as the result of a higher tides (Iglesias Darriba et al. 2017). However, materials of marine origin, e.g., mollusc shells and different highly eroded materials, are very rare. The organic matter deposited where the saltworks once stood may therefore have arrived: 1) in the form of human 
waste, or 2) via a stagnant water ecosystem under the influence of marine-littoral conditions, with contributions of vegetation from the river system that flowed into the surrounding salt marsh (Teira Brión 2010). However, the accumulation of waste from anthropogenic activities, such as debris, crafted objects, wooden tools (Martín-Seijo 2019), and the seeds and fruits of domestic and wild plant species, is evidence of strong human pressure from the nearby settlement; in effect, the abandoned saltworks was used as a dumping ground (Teira Brión 2010). This deposit has been dated to 259-280 and 335-416 cal A.D. (Figure 3), an estimate reached by combining the two radiocarbon dates available: Beta-267583:1720 \pm 40 B.P.

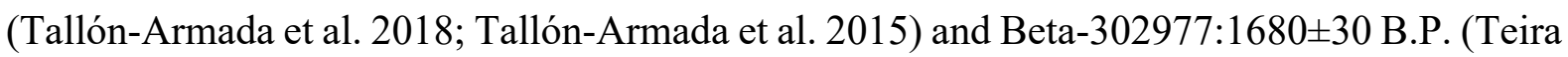
Brión 2013).

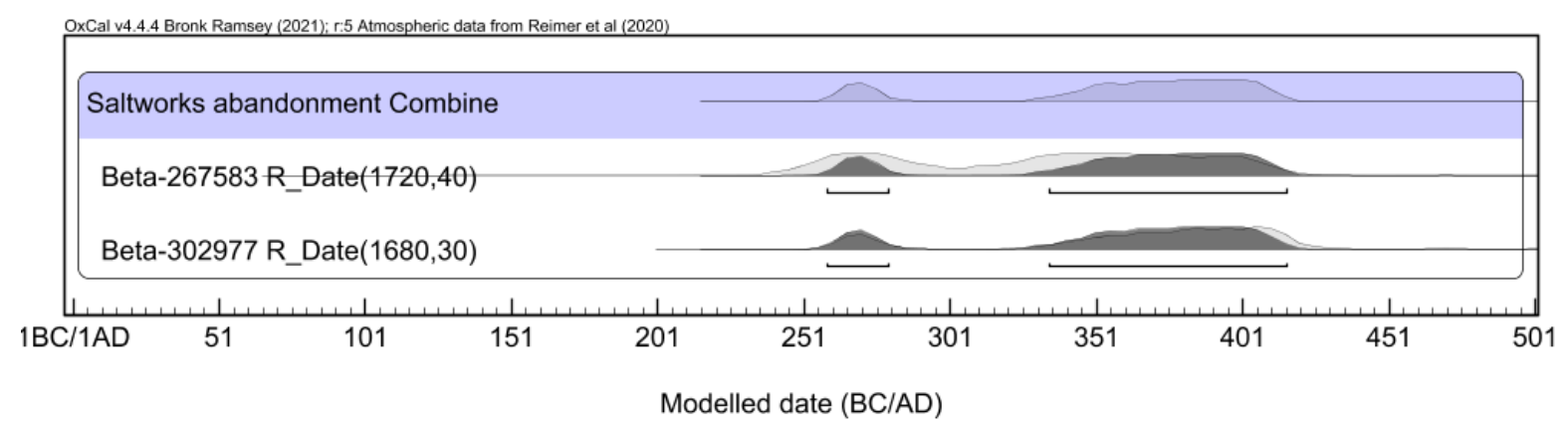

Figure 3 Chronology of the organic matter in the abandonment deposit, estimated using the Combine function in OxCal v.4.4.4. software (Bronk Ramsey 2009) and employing the IntCal20 curve (Reimer et al. 2020).

The above levels are overlain by a dune level. Indeed, the entire abandonment facies is marked by the appearance of sandy levels with aeolian morphological characteristics and edaphogenetic features suggesting a buried soil horizon and thus the stability of the above dune (Tallón-Armada et al. 2015). In the vicinity, and over part of the buried site, a burial and cremation necropolis began to appear in 350-400 A.D., lasting until the Early Middle Ages (César Vila 2010; Iglesias Darriba 2010; Valle Abad et al. 2020).

\section{Materials and methods}

The archaeobotanical samples examined in this work come from the Unidade de Actuación I06 in Rosalía de Castro Street, Vigo (Spain), an archaeological area that was excavated over five archaeological campaigns between 2006 and 2008. Their geographical location refers to the outline of the stratigraphic units of origin; xyz coordinates were not provided. The sediment comes from the deposit of organic matter that appeared after the abandonment of the saltworks, and from successive levels of fill that formed over the saltworks' ponds. Of the total 127 samples collected, 115 were analysed. Most were manually collected and included worked 
wooden objects and the remains of seeds and fruits; 29 samples were either wet or dry sediment that required processing to extract their contents (see below).

The majority of the examined remains were collected during the CD 102A 2006/368 campaign in sediment from stratigraphic unit SU1049, a wet and sandy-loamy deposit formed inside the evaporation ponds. This was covered by a sand dune up to $1 \mathrm{~m}$ in height with several levels of organic matter interspersed in its lower part. It preserved huge quantities of organic matter such as plant macrofossils -wood, fruits, seeds, leaves-, leather, fish scales and other ichthyological remains. Each sediment sample from SU1049 was sub-sampled (volume 3 L) and the contents analysed; the subsampling of small volumes of sediment has been shown sufficient for constructing representative records of wet sites for the study of their associated economy (Antolín et al. 2017b).

The dry sediment samples collected were processed using a flotation machine to recover the remains. The wet sediment samples, in contrast, were sieved to the wash-over technique in a bucket -no pressurised water was used- (Steiner et al. 2015). The floating material recovered using both techniques was poured onto sieves of 2,1 and $0.5-\mathrm{mm}$ mesh size for separation. Some of the organic material was subjected to desalination and the elimination of oil by means of a solution of water and neutral soap. This oil comes from spillages from a 20th century canning factory built over part of the archaeological area. The remains were stored immersed in still water inside rigid packaging and kept in a cold chamber to prevent the proliferation of microorganisms. Table 1 provides information on the sampling and processing performed.

Table 1 Archaeobotanical sampling performed during the archaeological excavations at the $\mathrm{O}$ Areal saltworks.

\begin{tabular}{|c|c|c|c|c|c|c|c|}
\hline \multirow[t]{2}{*}{ Intervention } & \multicolumn{5}{|c|}{ Sampling } & \multicolumn{2}{|l|}{ Remains } \\
\hline & $\begin{array}{l}\text { Total } \\
\text { samples }\end{array}$ & $\begin{array}{l}\text { Handpicked } \\
\text { samples }\end{array}$ & $\begin{array}{l}\text { Flotation } \\
\text { samples }\end{array}$ & $\begin{array}{l}\text { Wash- } \\
\text { over } \\
\text { samples }\end{array}$ & $\begin{array}{l}\text { Processed } \\
\text { volume } \\
\text { (litres) }\end{array}$ & Waterlogged & Charred \\
\hline $\begin{array}{l}\text { CD 102A } \\
2006 / 368\end{array}$ & 6 & 4 & 0 & 2 & 6 & 2675 & 5 \\
\hline $\begin{array}{l}\text { CD 102A } \\
2007 / 302\end{array}$ & 24 & 24 & 0 & 0 & 0 & 4 & \\
\hline $\begin{array}{l}\text { CD 102A } \\
2008 / 154\end{array}$ & 63 & 37 & 26 & 0 & 81.25 & 10 & \\
\hline $\begin{array}{l}\text { CD 102A } \\
2008 / 303\end{array}$ & 2 & 2 & 0 & 0 & 0 & 7 & \\
\hline $\begin{array}{l}\text { CD 102A } \\
2008 / 648\end{array}$ & 32 & 20 & 12 & 0 & 0 & 15 & \\
\hline Total & 127 & 87 & 38 & 2 & 87.25 & 2711 & 5 \\
\hline
\end{tabular}


The remains were then sorted according to their state of preservation using a trinocular microscope at 1-7x magnification. For material from the sediment, this was performed dry; for the waterlogged material it was sorted in a sheet of water to avoid moisture loss which would accelerate the rate of physical alteration or chemical degradation. The anatomical characteristics of seeds and fruits were compared against the reference collection of the Archaeobotanical Laboratory of the Universidade de Santiago and the specialised literature, mainly carpological atlases (Anderberg 1994; Bojnanský and Fargašová 2007; Cappers et al. 2012; Neef et al. 2012; Sabato and Peña-Chocarro 2021; Schöch et al. 1988).

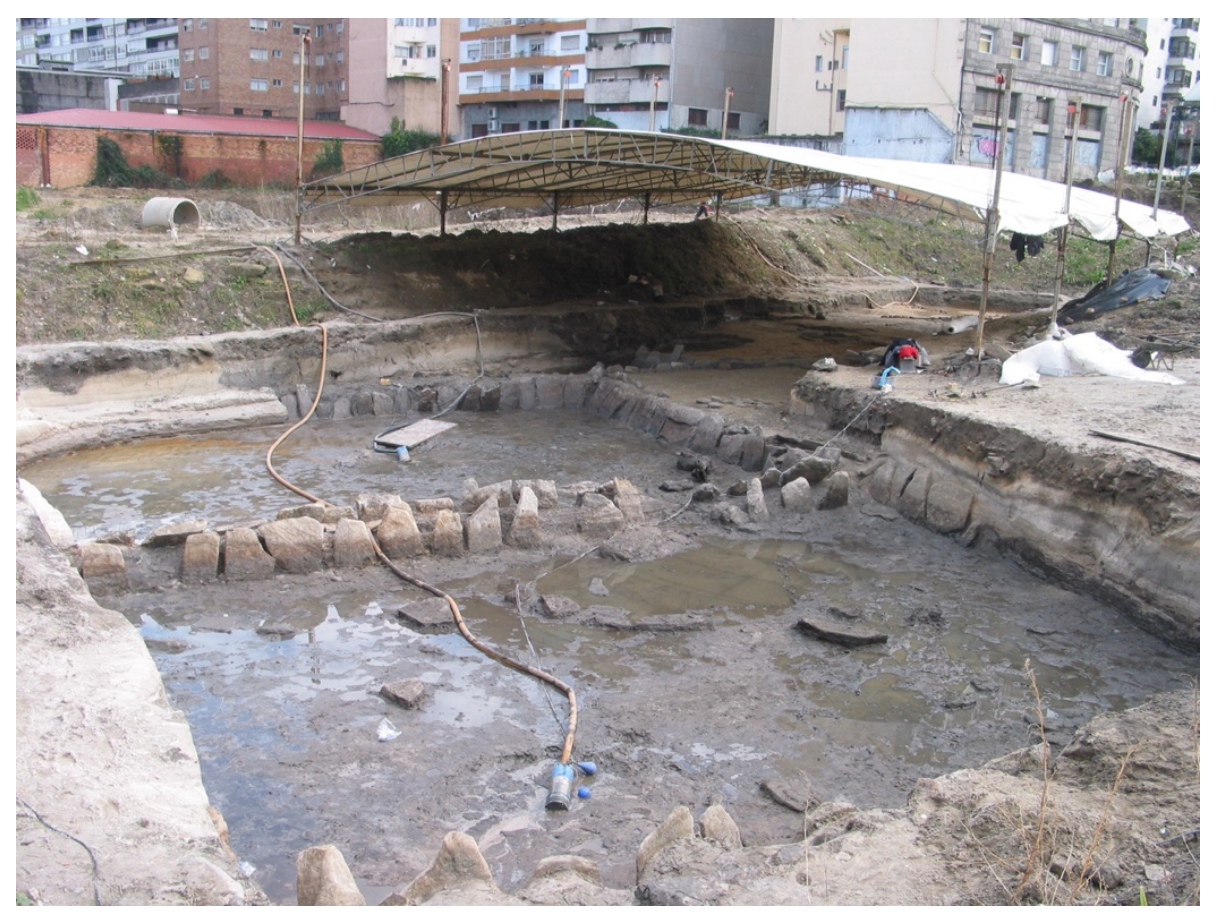

Figure 4. Evaporation ponds. The archaeobotanical remains were deposited on a stone slab/clay pavement and became covered by a dune. Photograph M. Á. Sartal Lorenzo.

\section{Results}

The total of 2716 carpological remains (individual seeds, seed fragments, and other plant parts) were recovered. Most were waterlogged; only five charred cereals remains were found. The concentration of carpological remains in the sediment samples from inside the evaporation ponds (SU1049) and processed by the wash-over technique was 1320/L, much greater than that obtained by flotation from samples taken outside of SU1049 (0.09/L). A total of 37 species and 13 genera within 28 families were identified; some could not be identified. These are high counts given the relatively small number of samples processed, and include plants cultivated 
and/or managed by humans, plus species that grew naturally but whose presence was influenced by the artificial environment produced by the saltworks. Table 2 summarises the species found and their abundance.

Table 2. Carpological results for each sample.

\begin{tabular}{|c|c|c|c|c|c|c|c|c|c|c|}
\hline \multirow[b]{4}{*}{ Group / Taxa } & \multirow{3}{*}{\begin{tabular}{|l} 
Intervention \\
Processing \\
Stratigraphic Unit \\
\end{tabular}} & \multirow{2}{*}{\multicolumn{2}{|c|}{$\begin{array}{c}\text { CD 102A } \\
2006 / 368 \\
\begin{array}{c}\text { Sediment (wash- } \\
\text { over) }\end{array}\end{array}$}} & \multirow{3}{*}{$\begin{array}{c}\begin{array}{c}\text { CD } \\
102 \mathrm{~A} \\
2007 / 302\end{array} \\
\begin{array}{c}\text { Hand- } \\
\text { picked }\end{array} \\
2188 \\
\end{array}$} & \multicolumn{3}{|c|}{ CD 102A 2008/154 } & $\begin{array}{c}\text { CD } \\
102 A \\
2008 / 303\end{array}$ & \multicolumn{2}{|c|}{ CD 102A 2008/648 } \\
\hline & & & & & \multicolumn{2}{|c|}{$\begin{array}{c}\text { Sediment } \\
\text { (flotation) }\end{array}$} & \multicolumn{4}{|c|}{ Handpicked } \\
\hline & & 1049 & 1049 & & 346 & 289 & 289 & 4040 & 2842 & 2233 \\
\hline & Sample & B2616 & B2548 & 18 & 3 & 37 & B44 & 1 & 6 & 7 \\
\hline \multirow[t]{3}{*}{ Cereals } & Hordeum vulgare (rachis) & 1 & & & & & & & & \\
\hline & Panicum miliaceum (lemma/palea) & 1508 & 9 & & & & & & & \\
\hline & Triticum aestivum/durum (seed) & & 4 & & & & & & & \\
\hline \multirow[t]{4}{*}{ Orchard/Garden } & Apium graveolens (mericarp) & 2 & 3 & & & & & & & \\
\hline & Cucumis melo (seed) & 3 & & & & & & & & \\
\hline & Cucumis melo/sativus (seed fragment) & & 1 & & & & & & & \\
\hline & Physalis alkekengi (seed) & 5 & 2 & & & & & & & \\
\hline \multirow[t]{18}{*}{ Arboriculture } & Castanea sativa (pericarp) & & 3 & & & & 1 & 1 & 1 & \\
\hline & Castanea sativa (pericarp fragment) & 339 & 277 & 1 & & & & & 1 & \\
\hline & Ficus carica (infructescence) & 17 & 11 & & & & & & & \\
\hline & Juglans regia (pericarp fragment) & 21 & 32 & & & & & 1 & & \\
\hline & Morus nigra (seed) & & 1 & & & & & & & \\
\hline & Olea europaea (seed) & & 1 & & & & & & & \\
\hline & Pinus pinea (bract) & & 3 & 1 & & & & 1 & 1 & \\
\hline & Pinus pinea (bract fragment) & 1 & & & & & & & & \\
\hline & Prunus avium (endocarp) & 8 & 1 & & & & & & & \\
\hline & Prunus avium (endocarp fragment) & & & & & & 2 & 2 & & \\
\hline & Prunus avium/cerasus (endocarp) & & 8 & & & & & & & \\
\hline & $\begin{array}{l}\text { Prunus avium/cerasus (endocarp } \\
\text { fragment) }\end{array}$ & 8 & & & & & & & & \\
\hline & Prunus domestica subsp. insititia (seed) & & 1 & & & & & & & \\
\hline & Prunus persica (endocarp) & & & 1 & & & & & 2 & \\
\hline & Prunus persica (endocarp fragment) & & 2 & 1 & & & & & & \\
\hline & Prunus sp (seed) & & 1 & & & & & & & \\
\hline & Vitis vinifera $($ seed) & 4 & 5 & & & 1 & & & & \\
\hline & Vitis vinifera (seed fragment) & 1 & 4 & & & & & & & \\
\hline \multirow[t]{7}{*}{ Ruderals/Weeds } & Atriplex prostrata (seed) & 2 & 1 & & & & & & & \\
\hline & cf Atriplex prostrata (seed) & & 1 & & & & & & & \\
\hline & Atriplex/Chenopodium (seed) & 1 & 5 & & & & & & & \\
\hline & Chenopodium album (seed) & 5 & 7 & & & & & & & \\
\hline & Chenopodium glaucum (seed) & & 1 & & & & & & & \\
\hline & Glebionis segetum (seed) & 1 & 2 & & & & & & & \\
\hline & Hyoscyamus niger (seed) & 2 & & & & & & & & \\
\hline
\end{tabular}




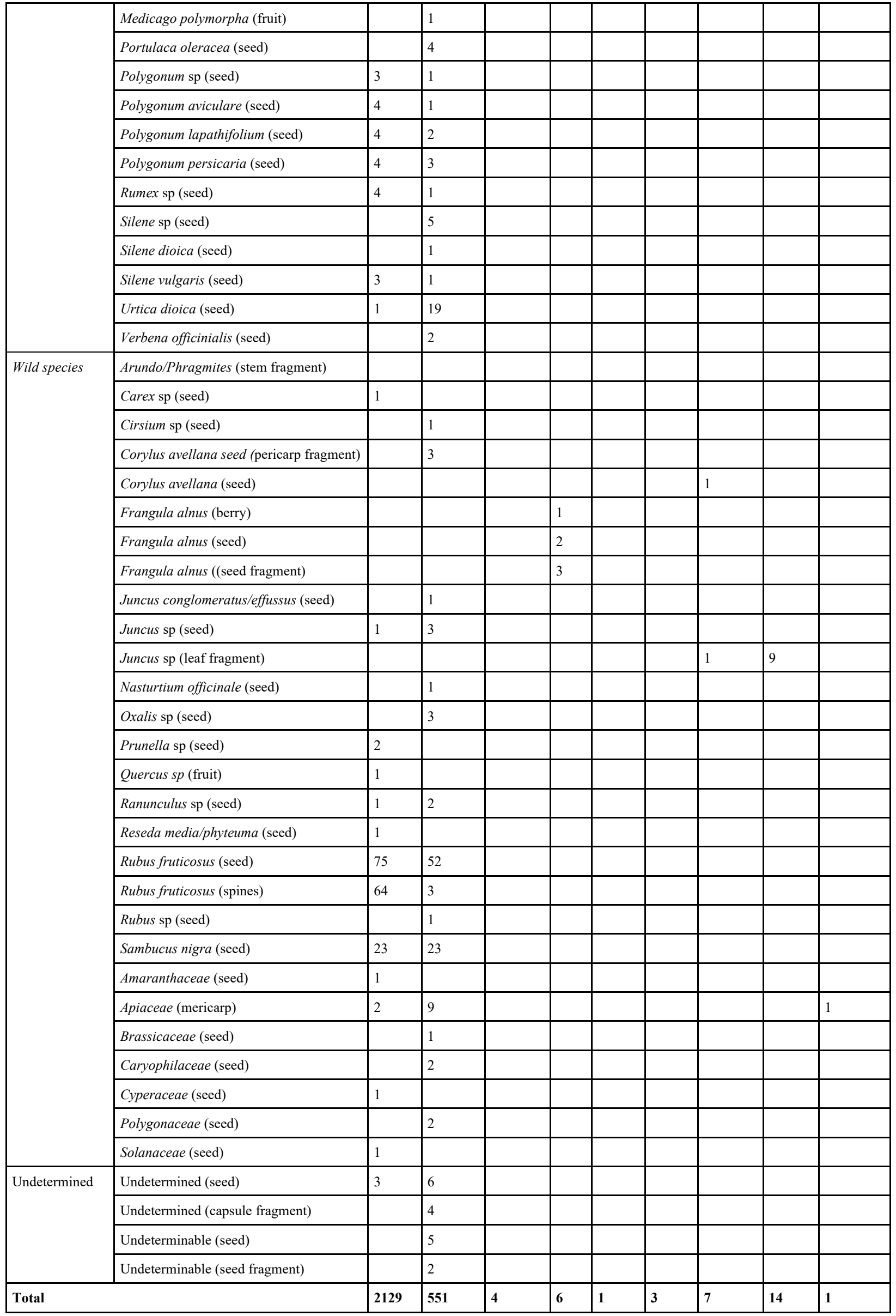




\subsection{Cereals}

Cereals were the best represented of all plant types in terms of abundance. Most remains corresponded to paleas and lemmas of broomcorn millet (Panicum miliaceum); indeed, this species accounted for $55.85 \%$ of the remains of the entire assemblage. Four caryopses of wheat (Triticum aestivum/durum) and one rachis of barley (Hordeum vulgare) were also documented. These species of the tribe Triticeae accounted for all five charred remains recovered.

\subsection{Horticultural and garden species}

Melon seeds (Cucumis melo) were recovered in small numbers. Remains of celery (Apium graveolens) and bladder cherry (Physalis alkekengi) were also found in small numbers. Notwithstanding the fact that celery and bladder cherry can be understood as wild plants, here it is proposed both species were cultivated (see Discussion).

\subsection{Fruit trees}

Fruit-tree and fruit-shrub species were well represented in the samples. Fragments of chestnut pericarps (Castanea sativa) made up more than $50 \%$ of the total for this group, few complete pericarps were detected. Other species recovered included walnut (Juglans regia), fig infructesences (Ficus carica), grapevine (Vitis vinifera), mulberry (Morus nigra), Prunaceae species such as sweet cherry (Prunus avium), peach (Prunus persica) and plum (Prunus domestica subsp. insititia) -all represented by endocarps-, olive (Olea europaea), and fragments of stone pine bracts (Pinus pinea).

\subsection{Weeds and ruderal species}

Many species of weed were identified, the growth of which may have been favoured by the niches created by agricultural exploitation (some are frequently present in communities associated with cereal fields). These included Chenopodium album, Glebionis segetum, Medicago polymorpha, Portulaca oleracea, Polygonum aviculare, Polygonum lapathifolium, Polygonum persicaria. Other species common in anthropised environments, such as Atriplex prostrata, Silene dioica, Silene vulgaris and Urtica dicoica, were also found.

\subsection{Wild plants}


Some of the documented remains belonged to fruit-bearing species, though no evidence of consumption was detected. These included an immature acorn of Quercus sp. and complete individuals (hazelnuts) of Corylus avellana, some with rodent bites, making it feasible that their presence is the result of transport or that they were simply natural inclusions. Elder (Sambucus nigra) and alder buckthorn (Frangula alnus) seeds and other remnants were also found. These plants grow naturally in humid environments in the northwestern Iberian Peninsula and produce fruits that may have provided human food. The presence of blackberry (Rubus fruticosus) seeds and spines indicates the existence of this plant in the surrounding area. Reeds (Arundo/Phragmites), compact rush (Juncus conglomeratus/effusus) and watercress (Nasturtium officinale) also found suitable places to grow; they may have formed part of the natural background or may have proliferated at the site. 


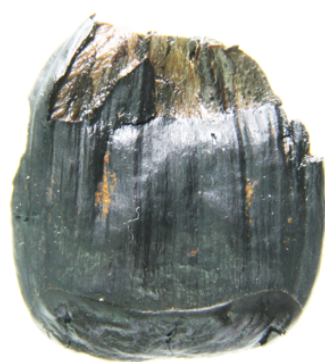

a

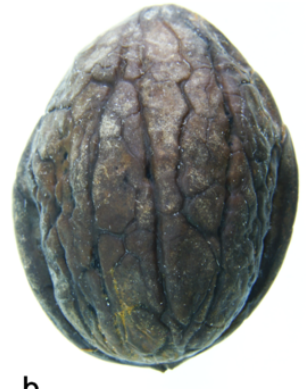

b

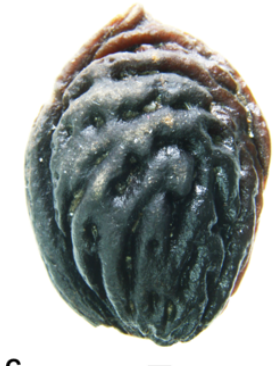

C

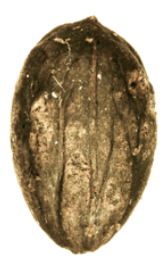

d

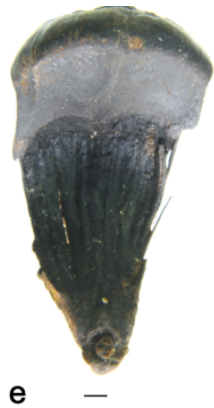

e

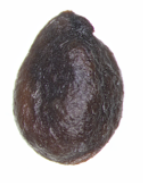

k
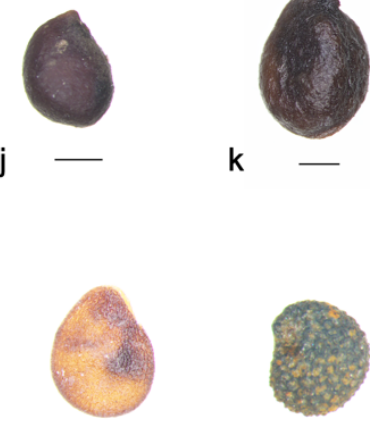

q
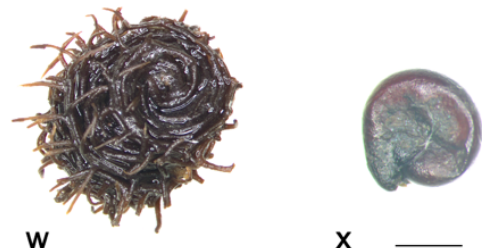

X
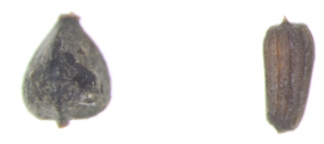

ae -

y

z
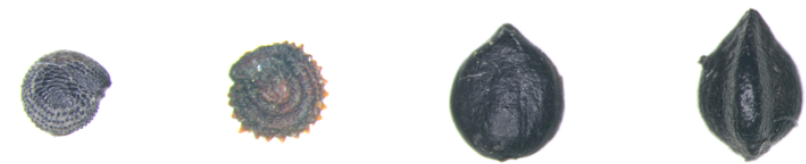

ab

ac

ad

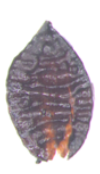

ai

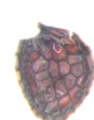

ah

ag

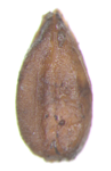

af
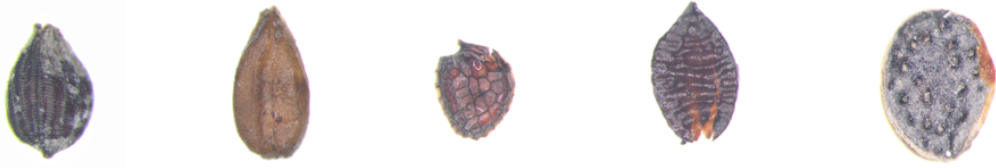

aj

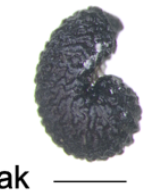

al

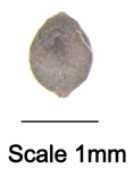

Figure 5 Carpological remains: a) Castanea sativa, b) Juglans regia, c) Prunus persica, d) Olea europaea, e) Pinus pinea, f) Prunus domestica subsp. insititia, g) Prunus avium, h) Frangula alnus, i) Vitis vinifera, j) Ficus carica, k) Morus nigra, 1) Cucumis melo, m) Panicum miliaceum, n) Triticum aestivum/durum, o) Hordeum vulgare, p) Apium graveolens, q) Physalis alkekenji, r) Hyoscyamus niger, s) Verbena officinalis, t) Rubus fruticosus, u) Sambucus nigra, v) Corylus avellana, w) Medicago polymorpha, x) Atriplex prostrata, y) Chenopodium album, z) Portulaca oleracea, aa) Silene vulgaris, ab) Polygonum lapathifolium, ac) Polygonum persicaria, ad) Carex sp., ae) Glebionis segetum, af) Juncus sp., ag) Prunella sp., ah) Nasturtium officinale, ai) Oxalis sp., aj) Ranunculus sp., ak) Reseda media/phyteuma. al) Urtica dioica. 


\section{Discussion}

The $\mathrm{O}$ Areal site contains a unique array of species that helps us understand the changes in the agricultural economy that occurred in the Iberian Peninsula during Roman times. However, care should be exercised when drawing conclusions. The primary context of the plants used for food is unknown, as are the areas where they were cultivated and the background against which they were processed. The examined remains were all found in a waste dump with anthropogenic and natural inputs, and although they are exceptionally well preserved, sampling was undertaken during excavation campaigns, making the results impossible compare with those obtained by systematic archaeobotanical sampling at other wet sites (cf. Antolín et al. 2017b; Maier and Harwath 2011, among others).

\subsection{Plants in the surroundings of O Areal}

The results indicate that different components of cereal processing were undertaken in the area around the saltworks. Although cereal caryopses are poorly preserved in damp environments, the woody parts of broomcorn millet were well preserved, providing the largest quantity of remains analysed for this species. These remains are likely a by-product of winnowing or the digested remains of animal feed. Two ways of dehusking the grain from the covers have been recorded for millet, namely pounding and grinding, which leaves the paleas and lemmas reduced to very small fragments (Moreno-Larrazabal et al. 2015; Teira Brión 2022). The intactness of many paleas and lemmas among the present remains thus rules out their processing for human consumption. The other cereals found, i.e., Triticum aestivum/durum and Hordeum vulgare, together with Panicum miliaceum, are the most common species found at sites with charred materials from this period (cf. Peña-Chocarro et al. 2019; Teira Brión 2019; Tereso et al. 2020; Tereso et al. 2013).

The finding of the remains of melons, which were widely consumed in antiquity, is indicative of the existence of probably areas given over to horticulture. Cucumis melo has been identified at Roman sites all over the Iberian Peninsula (Peña-Chocarro et al. 2019); it was originally introduced in the 9-8th century B.C. when the Phoenicians began to establish commercial settlements in southern Iberia (Pérez-Jordá et al. 2017). Plant such as celery was cultivated for food in many different regions of the Roman state (e.g. Bakels and Jacomet 2003; Van der Veen 2016). As well as in O Areal, celery it is documented in the Roman port of Irun (PeñaChocarro and Zapata 2005), although it is interpreted as a wild species in this site. 
It is difficult to establish whether other common and ruderal plants detected at $\mathrm{O}$ Areal were present in the natural environment or linked to gardens and horticultural land, as some of them were used in Roman times but this cannot be deduced from the samples analysed at the site. For example, bladder cherry is not naturally occurring in the northwestern Iberia (vid. Romero Buján 2008), but it was present in the wild in other areas of the Iberian Peninsula during prehistoric times (Antolín 2016). Its fruit has a diuretic effect and cures jaundice according to Dioscorides; therefore, bladder cherry may have been introduced into the settlement for medicinal or even ornamental purposes. Henbane is a good proxy for soil fertility due to their prevalence in rich soils (Grime et al. 1988) but it has also psychotropic properties highly appreciated by the Greek physician Dioscorides (De materia medica 4.68.1) in the 1st century A.D. (Scarborough 2018). Their seeds were used as a local anaesthetic and were prepared in an ointment with wool fat for treating soldiers' pain (Belfiglio 2017). Henbane has also been recorded at other sites in northwestern Iberia (Tereso et al. 2020; Vaz et al. 2017), although it has not been associated with any medicinal use and here is considered as a weed.

Perhaps the most important aspect of this archaeobotanical assemblage is the variety of consumable fruits identified. Ficus carica, Olea europaea, Prunus persica and Vitis vinifera were all domestic species widely distributed across Roman settlements (Peña-Chocarro et al. 2019). The introduction of domestic varieties of fruit trees occurred during the 1st millennium B.C. in the Mediterranean area (Pérez-Jordá et al. 2017), but in the archaeological sites of the northern Atlantic area of the Iberian Peninsula they are documented for the first time during the Roman Period. This points to chronological differences in the expansion of arboricultural practices and their associated species. The introduction of other fruit trees, such as mulberry (Morus nigra) and plum (Prunus domestica subsp. insititia) is linked to Roman conquest. The mulberry at $\mathrm{O}$ Areal is the oldest remain of this taxon found in the current state of the archaeobotanical literature in the Iberian Peninsula. The seed is within the usual measurements for the Morus nigra species, although some studies indicate that size alone is insufficient to properly distinguish Morus nigra from Morus alba (Durand et al. 2016).

Chestnut, walnut, cherry and stone pine have been grown in tree formations since ancient times (Carrión 2012), but they also grow wild, so it is hard to say whether wild or cultivated varieties provided the material at $\mathrm{O}$ Areal. The Iberian Peninsula was a glacial refuge for the chestnut (Roces-Díaz et al. 2018), and wild fig was present in natural environments during Prehistory (Carrión 2012). Olive has been documented at archaeological sites from the 1st millennium 
B.C. (Martín-Seijo et al. 2020; Silva 2008). All these species were potentially used for food, but no evidence is available of their use or transport to sites in northwestern Iberia or the Cantabrian area (northern Iberia) during the Iron Age. However, given the biography of these fruit trees and the frequency with which they began to appear in Roman settlements, the expansion of their cultivation and consumption probably began in Roman times.

The remains of fruits of Castanea sativa and Juglans regia were recovered in a highly fragmented state, perhaps indicating intentional fragmentation for consumption. It is also possible that part of the fruits was deposited as a natural inclusion due to the existence of specimens close to the saltworks; these may have then suffered degradation for different reasons (see Antolín et al. 2017a). However, the type of fragmentation seen for the bracts of Pinus pinea clearly indicates human action. Pine nuts and whole pine cones were found during the archaeological excavation (Benavides García 2010; Iglesias Darriba 2009) although they were not available for the present study.

The remains of adventitious and ruderal species were present. These taxa are compatible with a profoundly transformed environment, and are frequently found in hedges, along roads, and in fields, etc. Corylus avellana, Rubus fruticosus and Sambucus nigra were also detected among other species- but no evidence of their use or consumption was found.

\subsection{Roman towns as centres for the introduction of crops}

The O Areal site presents an assemblage of species with numerous parallels across Europe (Bakels and Jacomet 2003; Bosi et al. 2020; Jacomet and Vandorpe 2011; Livarda 2011; Lodwick 2017; Vandorpe 2010). Within the Iberian Peninsula, similarities can be seen in particular with the Roman port of Irun (Peña-Chocarro and Zapata 1997; Peña-Chocarro and Zapata 2005). The expansion of species during Roman times was linked to the appearance of urban areas, military camps and specialised production areas (Bakels and Jacomet 2003; Livarda 2011; Livarda and Orengo 2015; Lodwick 2017), contexts involving strong social interactions exposed to change. Urban areas represented dynamic settings that served as the entry points for new practices, customs and ideas being adopted throughout the Roman State. Certainly, O Areal was on the maritime routes running between the Atlantic and the Eastern Mediterranean, and the area could have been receptive to novel ideas. Not only the low cost of sea traffic would have been key, but also the terrestrial routes would have favoured the expansion of crops and agricultural practices. The land road networks would have internally 
connected the different productive regions, of which the northwest Iberian region was one of the most significant in economic terms (de Soto 2013; de Soto 2019).

The productive and administrative centres of the Roman Period would have favoured the expansion of arboriculture and acted as hubs for the consumption and redistribution of foodstuffs (Teira Brión and Rey Castiñeira 2021). They would have facilitated the arrival of new species but could also have served as sites for secondary domestication events thanks to the implementation of new agricultural practices in the management of local wild varieties. A previous morphometric study performed on vine seeds from $\mathrm{O}$ Areal made it possible to distinguish between those of Vitis vinifera subsp. vinifera and Vitis vinifera subsp. sylvestris, and detected specimens very similar to seeds of the current grape variety 'Albariño' (Boso et al. 2020). This might indicate a process of local domestication of wild subspecies (Boso et al. 2020), or the introgression of wild $V$. sylvestris in the study region. Genetic analyses of ancient grapevines from the neighbouring wine-growing region of Vinho Verde (in Portugal) pointed out the existence of introgression from wild plants into currently cultivated varieties (Cunha et al. 2020). Thus, in the surroundings of the saltworks, the agricultural practices followed could have favoured genetic exchange within the Iberian Northwest. If this domestication/introgression process is confirmed by future analyses, it may be necessary to think more along the lines of hybrid crop communities than any dichotomy between domestic and wild types. Introduced, domesticated and non-domesticated vines may all have been present and have been subject to the same agricultural management. The same may also have been the case for Castanea sativa, Juglans regia and Prunus avium.

The Roman Period witnessed a transformation in the productive landscape in terms of tree species. The cultivation of fruit trees required changes in spatial organisation, and a workforce dedicated to orchard maintenance and the distribution of the fruit to markets. Urban centres even generated new habitats mediated by humans, including the formation of gardens, and leisure spaces, and in these plants may have been cultivated for their beauty or medicinal properties. A conception of plants beyond their use as food or as part of a productive activity is provided by species grown for ornamental reasons, e.g., the cypress trees (Cupressus sempervirens) at the thermal baths of Aquae Flaviae (Vaz et al. 2016). Juglans regia and Pinus pinea/pinaster were also planted for funerary rites; the quality of their wood for crematory fires and their significance in Roman culture (Martín-Seijo and César Vila 2019) would have made them good choices. 


\section{Conclusions}

The state of preservation of the waterlogged materials at $\mathrm{O}$ Areal allowed the identification of species not commonly found at sites in the Iberian Peninsula, where the macroremains of fruits and seeds are usually preserved either in carbonised or mineralised form. They also allow the biography and consumption of plants to be traced during the Roman Period in the northwest of the Iberian Peninsula and reflect the transformations in agricultural practices that were underway such as arboriculture. The tree and shrub species detected, i.e., Castanea sativa, Juglans regia, Morus sp, Pinus pinea, Prunus avium, Prunus domestica subsp. insititia, Prunus persica and Vitis vinifera reached different corners of the Iberian Peninsula during this period. Other species, such as the cereals Panicum miliaceum, Triticum aestivum/durum, Hordeum vulgare, and horticultural species such as Cucumis melo and, probably, Apium graveolens and Physalis alkekengi, were also detected, as were several species belonging to weed communities linked to cropland. The results also provide data on the surrounding plant communities. Although the influence of a productive and strongly altered area for making salt influenced the composition of the archaeobotanical assemblage, some of the taxa identified would have grown naturally, occupying different niches. Thus, although the O Areal saltworks was abandoned and became a dumping ground, the components of its archaeobotanical assemblage have different origins, including coastal environments, damp areas, open woodland, cultivated areas, and crop-processing areas.

\section{Acknowledgements}

Analyses were performed at the Laboratory of Archaeobotany, Universidade de Santiago de Compostela. The author thanks Miguel Sartal Lorenzo and María Jesús Iglesias Darriba (Adro Arqueolóxica S.L.) and Mario César Vila (P\&A Arqueólogos S.L.) -the directors of the different archaeological excavations at the site- who were responsible for collecting the samples examined.

\section{References}

Alfaro Giner C (2010) La mujer y el trabajo en la Hispania prerromana y romana: actividades domésticas y profesionales Mélanges de la Casa de Velázquez 40:15-38 doi:https://doi.org/10.4000/mcv.3540

Almeida F, Ferreira OdV (1967) Um poço lusitano-romano encontrado em Idanha-a-Velha O arqueólogo português Série III 1:57-63 
Alonso Martínez N (2005) Agriculture and food from the Roman to the Islamic Period in the North-East of the Iberian peninsula: archaeobotanical studies in the city of Lleida (Catalonia, Spain) Vegetation history and archaeobotany 14:341-361 doi:https://doi.org/10.1007/s00334-005-0089-4

Anderberg A-L (1994) Atlas of seeds and small fruits of Northwest-European plant species with morphological descriptions Stockholm: Part 4

Antolín F (2016) Local, intensive and diverse? Early farmers and plant economy in the NorthEast of the Iberian Peninsula (5500-2300 cal BC). Barkhuis Publishing, Groningen

Antolín F, Steiner BL, Akeret Ö, Brombacher C, Kühn M, Vandorpe P, Bleicher N, Gross E, Schaeren G, Jacomet S (2017a) Studying the preservation of plant macroremains from waterlogged archaeological deposits for an assessment of layer taphonomy Review of palaeobotany and palynology

doi:https://doi.org/10.1016/j.revpalbo.2017.06.010

246:120-145

Antolín F, Steiner BL, Jacomet S (2017b) The bigger the better? On sample volume and the representativeness of archaeobotanical data in waterlogged deposits Journal of Archaeological Science: Reports 12:323-333 doi:https://doi.org/10.1016/j.jasrep.2017.02.008

Bakels C, Jacomet S (2003) Access to luxury foods in Central Europe during the Roman period: the archaeobotanical evidence World Archaeology 34:542-557 doi:https://doi.org/10.1080/0043824021000026503

Belfiglio VJ (2017) Control of epidemics in the Roman army: 27 B.C. - A.D. 4762017 4:5 doi:https://doi.org/10.18203/2394-6040.ijcmph20171745

Benavides García R (2010) Conservación de materiais orgánicos empapados das salinas romanas de Rosalía de Castro II, Vigo (Pontevedra). In: Xunta de G (ed) Actuacións Arqueolóxicas. Ano 2008. Xunta de Galicia, Santiago de Compostela, pp 351-352

Bleicher N, Schubert C (2015) Why are they still there? A model of accumulation and decay of organic prehistoric cultural deposits Journal of Archaeological Science 61:277-286 doi:https://doi.org/10.1016/j.jas.2015.06.010

Bojnanský V, Fargašová A (2007) Atlas of seeds and fruits of Central and East-European flora: the Carpathian Mountains region. Springer Science \& Business Media, Dordrecht

Bosi G, Castiglioni E, Rinaldi R, Mazzanti M, Marchesini M, Rottoli M (2020) Archaeobotanical evidence of food plants in Northern Italy during the Roman period Vegetation History and Archaeobotany 29:681-697 doi:https://doi.org/10.1007/s00334-020-00772-4

Boso S, Gago P, Santiago JL, Teira-Brión A, Martín-Seijo M, Rey-Castiñeira J, Ocete R, Ocete C, Martínez MC (2020) Morphometric comparison of current, Roman-era and medieval Vitis seeds from the north-west of Spain Australian Journal of Grape and Wine Research 26:300-309 doi:https://doi.org/10.1111/ajgw.12439

Bronk Ramsey C (2009) Bayesian Analysis of Radiocarbon Dates Radiocarbon 51:337-360 doi:https://doi.org/10.2458/azu is rc.51.3494

Brun J-P (2004) Archéologie du vin et de l'huile dans l'Empire romain. Errance, Paris

Buxó R (2008) The agricultural consequences of colonial contacts on the Iberian Peninsula in the first millennium BC Vegetation History and Archaeobotany 17:145-154 doi:https://doi.org/10.1007/s00334-007-0133-7 
Cappers RTJ, Bekker RM, Jans JEA (2012) Digitale Zadenatlas van Nederland/Digital seed atlas of the Netherlands vol 4. Barkhuis publishing \& Groningen University Library, Groningen

Carreras C, Morais R (2012) The Atlantic Roman trade during the Principate: new evidence from the western façade Oxford Journal of Archaeology 31:419-441 doi:https://doi.org/10.1111/j.1468-0092.2012.00396.x

Carrión JS (2012) Paleoflora y paleovegetación de la peninsula Ibérica e Islas Baleares: Plioceno-Cuaternario. $1^{\mathrm{a}}$ edición edn. Ministerio Economía y competitividad, Universidad de Murcia, Fundación Séneca, Murcia

Castro Carrera JC (2006) La salina romana de « O Areal », Vigo (Galice). In: Jean-Claude H, Sarrazin J-L (eds) Le sel de la Baie : Histoire, archéologie, ethnologie des sels atlantiques. Presses universitaires de Rennes, Rennes, pp 105-122

Castro Carrera JC (2007) La salina romana del yacimiento de "O Areal", Vigo (Galicia): un complejo industrial salazonero altoimperial. In: Lagóstena L, Bernal D, Arévalo A (eds) CETARIAE 2005: Salsas y Salazones de Pescado en Occidente durante la Antigüedad, vol 1686. BAR International Series, Oxford, pp 355-365

Castro Carrera JC, Prieto Robles S, Sartal Lorenzo M, Acuña Piñeiro Á, Iglesias Darriba MJ, Rodríguez Saiz E, Tallón Armada R, Fernández Fernández A (2019) La salina romana de evaporación solar de O Areal-Vigo (Galicia, España). Un ejemplo de arquitectura “efímera" conservada. In: Morillo Cerdán Á, Hermanns MH, Salido Domínguez J (eds) Ephemeral Archaeology / Arqueología Efímera. Nünneric-Asmus Verlag \& Media, Mainz am Rhein, pp 127-142

César Vila M (2010) Escavación arqueolóxica en área da parcela 4 da Unidade de actuación I06, Rosalía de Castro no 2, Vigo. In: Xunta de G (ed) Actuacións Arqueolóxicas. Ano 2008. Xunta de Galicia, Santiago de Compostela, pp 202-203

Corrales Aguilar P (2011-2012) Aceite y salazones como base de la economía malacitana en época imperial Anales de Prehistoria y Arqueología 27-28:431-440

Cunha J, Ibáñez J, Teixeira-Santos M, Brazão J, Fevereiro P, Martínez-Zapater JM, Eiras-Dias JE (2020) Genetic Relationships Among Portuguese Cultivated and Wild Vitis vinifera L. Germplasm Frontiers in Plant 11 doi:https://doi.org/10.3389/fpls.2020.00127

Currás BX (2017) The salinae of O Areal (Vigo) and Roman salt production in NW Iberia Journal of Roman Archaeology 30:325-349 doi:https://doi.org/10.1017/S1047759400074146

Currás Refojos BX (2007) Aportación al conocimiento de la industria de salazón en las Rías Baixas Gallegas. In: Actas del Congreso Internacional CETARIAE. Salsas y salazones de pescado en Occidente durante la Antigüedad. Universidad de Cádiz edn. B.A.R. international series, Oxford, pp 135-149

de Soto P (2013) Los sistemas de transporte romanos y la configuración territorial en el noroeste peninsular. In: Morais R, Granja H, Morillo Cerdán Á (eds) O Irado Mar Atlantico. O naufrágio bético augustano de Esposende (Norte de Portugal). Museo de Arqueologia Diogo de Sousa, Braga,

de Soto P (2019) Network Analysis to Model and Analyse Roman Transport and Mobility. In: Verhagen P, Joyce J, Groenhuijzen MR (eds) Finding the Limits of the Limes: 
Modelling Demography, Economy and Transport on the Edge of the Roman Empire. Springer International Publishing, Cham, pp 271-289. doi:10.1007/978-3-030-04576$0 \_13$

Durand A, Bouby L, Chabal L, Mane P, Ruas M-P (2016) Histoire et utilisations des mûriers blanc e noir en France. Apports de l'archéobotanique, des textes et de l'iconographie. In: Ruas M-P (ed) Des fruits d'ici et d'ailleurs-Regards sur l'histoire de quelques fruits consommés en Europe. colleciton Historie des Savoirs. Éditions Omniscience, Paris, pp 213-322

Expósito Álvarez JÁ (2011) La industria salazonera de época romana. El contexto del Sinus Gaditanus. In: Díaz JJ, Sáez AM, Vijande E, Lagóstena J (eds) Estudios recientes de Arqueología Gaditana, vol Actas de las Jornadas de Jóvenes Investigadores Prehistoria \& Arqueología (Cádiz, abril 2008). vol BAR International Series 2276. Archaeopress, Oxford, pp 213-233

Freitas S, Gazda MA, Rebelo M, Muñoz-Pajares AJ, Vila-Viçosa C, Muñoz-Mérida A, Gonçalves LM, Azevedo-Silva D, A fonso S, Castro I, Castro PH, Sottomayor M, BejaPereira A, Tereso J, Ferrand N, Gonçalves E, Martins A, Carneiro M, Azevedo H (2021) Evidence of post-domestication hybridization and adaptive introgression in Western European grapevine varieties bioRxiv doi:https://doi.org/10.1101/2021.03.03.432021

García Vargas E, Bernal Casasola D Roma y la producción de "garvm" y "salsamenta" en la costa meridional de "Hispani": estado actual de la investigación. In: Bernal Casasola D (ed) Arqueología de la pesca en el Estrecho de Gibraltar: de la Prehistoria al fin del Mundo Antiguo, 2009. Monografías del proyecto SAGENA 1. Servicio de Publicaciones, pp 133-182

García Vargas E, Martínez Maganto J (2017) Salines d'évaporation solaire dans l'Empire romain : témoignages archéologiques d'une activité éphémère. In: González Villaescusa R, Schörle K, Gayet F, Rechin F (eds) L'exploitation des ressources maritimes de l'Antiquité: activités productives et organisations des territoires. Éditions APDCA, Antibes, pp 197-212

González Gómez de Agüero E (2013) La ictiofauna e los yacimientos arqueológicos del Noroeste de la Península Ibérica. Universidad de León

Grime JP, Hodgson JG, Hunt R (1988) Comparative Plant Ecology. A Functional Approach to Common British Species. Unwin Hyman, London. doi:10.1007/978-94-017-1094-7

Iglesias Darriba MJ (2009) Avaliación arqueolóxica das parcelas 6, 10, 6 anexo e 3 anexo, da Unidade de Actuación I-06, Rosalía de Castro II, Vigo. In: Galicia Xd (ed) Actuacións Arqueolóxicas. Ano 2007. Xunta de Galicia, Santiago de Compostela, pp 174-175

Iglesias Darriba MJ (2010) Avaliación arqueolóxica da parcela 3 da Unidade de actuación I06 de Rosalía de Castro II, Vigo. In: Xunta de G (ed) Actuacións Arqueolóxicas. Ano 2008. Xunta de Galicia, Santiago de Compostela, pp 206-207

Iglesias Darriba MJ, Acuña Piñeiro Á, Castro Carrera JC, Prieto Robles S, Sartal Lorenzo M, Rodríguez Saiz E, Fernández Fernández A (2017) Estudio preliminar de la salina romana de evaporación solar de O Areal-Vigo (Galicia, España). In: González Villaescusa R, Schörle K, Gayet F, Rechin F (eds) L'exploitation des ressources maritimes de l'Antiquité: activités productives et organisations des territoires. Éditions APDCA, Antibes, pp 213-233 
Jacomet S, Vandorpe P (2011) Plantes anciennes et nouvelles. La région du Rhin supérieur et l'Allemagne du Sud-Ouest. In: Reddé M et al. (eds) Aspects de la Romanisation dans l'Est de la Gaule, vol 21. Bibracte, Glux-en-Glenne, pp 345-360

Lewit T (2020) "terris, vineis, olivetis...": wine and oil production after the villas European Journal of Post-Classical Archaeologies 10:193-217

Livarda A (2011) Spicing up life in northwestern Europe: exotic food plant imports in the Roman and medieval world Vegetation History and Archaeobotany 20:143-164 doi:https://doi.org/10.1007/s00334-010-0273-z

Livarda A, Orengo HA (2015) Reconstructing the Roman London flavourscape: new insights into the exotic food plant trade using network and spatial analyses Journal of Archaeological Science 55:244-252 doi:https://doi.org/10.1016/j.jas.2015.01.008

Lodwick L (2017) Arable farming, plant foods and resources. In: Brindle T, Smith AT, Allen MG, Fulford M, Lodwick L (eds) The Rural Economy of Roman Britain, vol New Visions of the Countryside of Roman Britain, 2. vol Britannia Monograph series 30. Society for the Promotion of Roman Studies, London, pp 11-84

Maier U, Harwath A (2011) Detecting intra-site patterns with systematic sampling strategies. Archaeobotanical grid sampling of the lakeshore settlement Bad Buchau-Torwiesen II, southwest Germany Vegetation History and Archaeobotany 20:349-365 doi:https://doi.org/10.1007/s00334-011-0295-1

Martín i Oliveras A, Martín-Arroyo Sánchez DJ, Revilla Calvo V (2017) The wine economy in Roman Hispania. Archaeological data and modellization. In: Remesal Rodríguez J (ed) Economía romana. Nuevas perspectivas/The roman economy. New perspectives. Universitat de Barcelona, Barcelona, pp 189-237

Martín Seijo M, Rico Rey A, Teira Brión A, Picón Platas I, García González I, Abad Vidal E (2010) Guía de Arqueobotánica vol Arqueoloxía/Guías Metodolóxicas 1. Xunta de Galicia, Santiago de Compostela

Martín-Seijo M (2019) Madera y sal: estructuras y objets de madera recuperados en las salinas romanas de O Areal (Vigo, Galicia). In: Morillo Cerdán Á, Hermanns MH, Salido Domínguez J (eds) Ephemeral Archaeology / Arqueología Efímera. Nünneric-Asmus Verlag \& Media, Mainz am Rhein, pp 179-192

Martín-Seijo M, César Vila M (2019) Oak, Ash and Pine: The Role of Firewood in Funerary Rituals at the Roman Site of Reza Vella (Ourense, Spain) Archaeological and Anthropological Sciences 11:1911-1926 doi:https://doi.org/10.1007/s12520-018$\underline{0641-7}$

Martín-Seijo M, Teira-Brión A, Currás A, Rodríguez-Rellán C (2020) After the fire: the end of a house life-cycle at the Iron Age site of Nabás (North-western Iberia) Vegetation History and Archaeobotany 29:427-446 doi:https://doi.org/10.1007/s00334-019$\underline{00750-5}$

Moreno-Larrazabal A, Teira-Brión A, Sopelana-Salcedo I, Arranz-Otaegui A, Zapata L (2015) Ethnobotany of millet cultivation in the north of the Iberian Peninsula Vegetation History and Archaeobotany 24:541-554 doi:https://doi.org/10.1007/s00334-015-0518Y

Neef R, Cappers RTJ, Bekker RM (2012) Digital Atlas of Economic Plants in Archaeology. Barkhuis \& Groningen University Library, Groningen 
Peña-Chocarro L, Pérez-Jordà G, Alonso N, Antolín F, Teira-Brión A, Tereso JP, Montes Moya EM, López Reyes D (2019) Roman and Medieval crops of the Iberian Peninsula: a first synthesis of seeds and fruits from archaeological sites Quaternary International 499:49-66 doi:https://doi.org/10.1016/i.quaint.2017.09.037

Peña-Chocarro L, Zapata L (1997) Higos, ciruelas y nueces: aportación de la arqueobotánica al estudio del mundo romano Isturitz 9:679-690

Peña-Chocarro L, Zapata L (2005) Trade and new plant foods in the western Atlantic coast: The Roman port of Irun (Basque Country). In: Urteaga Artigas MM, Noain Maura MJ (eds) Mar Exterior. El Occidente Atlántico en época romana. Actas del Congreso Internacional. Pisa, 6-9 noviembre 2003. Roma. Escuela Española de Historia y Arqueología en Roma-CSIC, Roma, pp 159-167

Pérez-Jordá G, Peña-Chocarro L, García Fernández M, Vera Rodríguez JC (2017) The beginnings of fruit tree cultivation in the Iberian Peninsula: plant remains from the city of Huelva (southern Spain) Vegetation History and Archaeobotany:1-12 doi:https://doi.org/10.1007/s00334-017-0610-6

Pérez-Jordà G, Peña-Chocarro L, Pardo-Gordó S (2021) Fruits arriving to the west. Introduction of cultivated fruits in the Iberian Peninsula Journal of Archaeological Science: Reports 35:102683 doi:https://doi.org/10.1016/j.jasrep.2020.102683

Reimer PJ, Austin WEN, Bard E, Bayliss A, Blackwell PG, Bronk Ramsey C, Butzin M, Cheng H, Edwards RL, Friedrich M, Grootes PM, Guilderson TP, Hajdas I, Heaton TJ, Hogg AG, Hughen KA, Kromer B, Manning SW, Muscheler R, Palmer JG, Pearson C, van der Plicht J, Reimer RW, Richards DA, Scott EM, Southon JR, Turney CSM, Wacker L, Adolphi F, Büntgen U, Capano M, Fahrni SM, Fogtmann-Schulz A, Friedrich R, Köhler P, Kudsk S, Miyake F, Olsen J, Reinig F, Sakamoto M, Sookdeo A, Talamo S (2020) The IntCal20 Northern Hemisphere Radiocarbon Age Calibration Curve (0-55 cal kBP) Radiocarbon 62:725-757 doi:10.1017/RDC.2020.41

Riaz S, De Lorenzis G, Velasco D, Koehmstedt A, Maghradze D, Bobokashvili Z, Musayev M, Zdunic G, Laucou V, Andrew Walker M, Failla O, Preece JE, Aradhya M, ArroyoGarcia R (2018) Genetic diversity analysis of cultivated and wild grapevine (Vitis vinifera L.) accessions around the Mediterranean basin and Central Asia BMC Plant Biology 18:137 doi:https://doi.org/10.1186/s12870-018-1351-0

Roces-Díaz JV, Jiménez-Alfaro B, Chytrý M, Díaz-Varela ER, Álvarez-Álvarez P (2018) Glacial refugia and mid-Holocene expansion delineate the current distribution of Castanea sativa in Europe Palaeogeography, Palaeoclimatology, Palaeoecology 491:152-160 doi:https://doi.org/10.1016/j.palaeo.2017.12.004

Rodríguez Martínez RM, Aboal Fernández R, Castro Hierro V, Cancela Cereijo C, Ayán Vila XM (2011) Una posible factoría prerromana en el noroeste. Primeras valoraciones de la intervención en el campo de A Lanzada (Sanxenxo, Pontevedra) Férvedes 7:167-173

Rodríguez Neila JF, González Román C, Mangas Manjarrés J, Orejas Saco del Valle A (1999) El Trabajo en la Hispania romana. Sílex, Madrid

Romero Buján MI (2008) Catálogo da Flora de Galicia. Universidade de Santiago de Compostela, Lugo

Rubio-Campillo X, Montanier J-M, Rull G, Bermúdez Lorenzo JM, Moros Díaz J, Pérez González J, Remesal Rodríguez J (2018) The ecology of Roman trade. Reconstructing 
provincial connectivity with similarity measures Journal of Archaeological Science 92:37-47 doi:https://doi.org/10.1016/j.jas.2018.02.010

Sabato D, Peña-Chocarro L (2021) Maris Nostri Novus Atlas: Seeds and fruits from the Mediterranean Basin. Doce Calles, Aranjuez

Scarborough J (2018) Pharmacology in the Early Roman Empire: Dioscorides and His Multicultural Gleanings. In: Keyser PT, Scarborough J (eds) Oxford Handbook of Science and Medicine in the Classical World. Oxford University Press, Oxford. doi:https://doi.org/10.1093/oxfordhb/9780199734146.013.24

Schöch WH, Pawlik B, Schweingruber FH (1988) Botanische Makroreste. Haupt, Bern

Silva MdFMd (2008) O povoamento proto-histórico e a romanizaçao da Bacia superior do Rio Coura: Estudo, Musealizaçao e Divulgaçao. Universidad de Granada

Steiner BL, Antolín F, Jacomet S (2015) Testing of the consistency of the sieving (wash-over) process of waterlogged sediments by multiple operators Journal of Archaeological Science: Reports 2:310-320 doi:http://dx.doi.org/10.1016/j.jasrep.2015.02.012

Tallón-Armada R, Costa-Casais M, Blanco-Chao R, Taboada Rodríguez T, Martínez-Cortizas A (2018) Paleoenvironmental reconstruction of an urban archaeological site: The Roman Salt mines of Vigo, northwest Iberia Geoarchaeology 33:112-126 doi:https://doi.org/10.1002/gea.21648

Tallón-Armada R, Costa-Casais M, Taboada Rodríguez T (2015) Evolución de un sector costero durante la Alta Edad Media en el NW de la Península Ibérica Estudos do Quaternário / Quaternary Studies 12:27-38

Teira Brión A (2010) Wild fruits, domesticated fruits. Archaeobotanical remains from the Roman saltworks at O Areal, Vigo (Galicia, Spain). In: Delhon C, Théry-Parisot I, Tiébault $\mathrm{S}$ (eds) Des hommes et des plantes. Exploitation du milieu et gestión des resources végétales de la Préhistoire à nous jours, vol XXXe rencontres internationales d'archéologie et d'histoire d'Antibes. Éditions APDCA, Antibes, pp 199-207

Teira Brión A (2013) Dentro y fuera del bosque: La gestión de Prunus avium/cerasus en época romana y medieval en el NW ibérico ArkeoGazte 3:99-115

Teira Brión A (2019) Cambio e resiliencia na agricultura e xestión de recursos vexetais no NW da Península Ibérica (1000 a.n.e.-400 d.n.e.). Thesis, Universidade de Santiago de Compostela

Teira Brión A (2022) Traditional millet cultivation in the Iberian Peninsula. Ethnoarchaeological reflections through the lens of social relations and economic concerns. In: Kirleis W, Dal Corso M, Filipović D (eds) Millet and what else? The wider context of the adoption of millet cultivation in Europe, vol Proceedings of the workshop held in Kiel on 27-28 November 2019. vol 14. Sidestone Press, Leiden,

Teira Brión A, Rey Castiñeira J (2021) Evidencias arqueobotánicas para una historia del consumo y producción de vino en el Noroeste ibérico SPAL - Revista de Prehistoria y Arqueología 30:165-195 doi:https://doi.org/10.12795/spal.2021.i30.06

Tereso JP, Pereira SS, Santos F, Seabra L, Vaz F (2020) Cultivos de época romana no Baixo Sabor: continuidade em tempos de mudança? In: Arqueologia em Portugal. 2020 Estado da Questão. Associação dos Arqueólogos Portugueses e CITCEM, Lisboa. doi:https://doi.org/10.21747/978-989-8970-25-1/arqa87 
Tereso JP, Ramil-Rego P, Almeida-da-Silva R (2013) Roman agriculture in the conventus Bracaraugustanus (NW Iberia) Journal of Archaeological Science 40:2848-2858 doi:https://doi.org/10.1016/i.jas.2013.01.006

Urteaga Artigas MM (2003) El puerto romano de Oiasso (Irún) y la desembocadura del río Bidasoa. In: Fernández Ochoa C (ed) Gijón puerto romano. Lunwerb, Gijón, pp 192211

Urteaga Artigas MM, Gereñu Urzelai MA (2003) Planificación de las excavaciones arqueológicas en sedimentos inundados: la experiencia del centro de estudios ARKEOLAN Monte Buciero 9:431-457

Valle Abad P, Fernández Fernández A, Acuña Piñeiro Á (2020) Analysis of the Western LateRoman Cemetery of O Areal: Example of an Atlantic Coastal Funerary Site in the Harbour of Vigo (Spain) Journal of Maritime Archaeology 15:393-414 doi:https://doi.org/10.1007/s11457-020-09274-w

Van der Veen M (2016) Arable Farming, Horticulture, and Food: Expansion, Innovation, and Diversity in Roman Britain. In: Millett M, Revell L, Moore A (eds) The Oxford Handbook of Roman Britain. Oxford University Press, Oxford, pp 807-833. doi:10.1093/oxfordhb/9780199697731.013.046

Vandorpe P (2010) Plant macro remains from the 1st and 2nd Cent. AD in Roman Oedenburg/Biesheim-Kunheim (F): methodological aspects and insights into local nutrition, agricultural practices, import and the natural environment. Tese, University of Basel

Vaz FC, Martín-Seijo M, Carneiro S, Tereso JP (2016) Waterlogged plant remains from the Roman healing spa of Aquae Flaviae (Chaves, Portugal): Utilitarian objects, timber, fruits and seeds Quaternary International 404:86-103 doi:http://dx.doi.org/10.1016/j.quaint.2015.09.063

Vaz FC, Seabra L, Tereso JP, Carvalho TPd (2017) Combustível para um forno: dinâmicas de ocupação de um espaço em Monte Mozinho (Penafiel) a partir de novos dados arqueobotânicos Arqueologia em Portugal/2017-Estado da Questão:1331-1345

Wiethold J (2003) How to trace the 'Romanisation' of central Gaul by archaeobotanical analysis? - Some considerations on new archaeobotanical results from France CentreEst. In: Favory F, Vignot A (eds) Actualités de la Recherche en Histoire et Archéologie agraires. Actes du colloque international AGER V, Besançon 2000, vol Annales Littéraires, 764. vol Série 'Environnement, sociétés et archéologie. Presses Universitaires Franc-Comtoises, Besançon, pp 269-282

Zech-Matterne V, Fiorentino G (eds) (2017) AGRUMED: Archaeology and history of citrus fruit in the Mediterranean : Acclimatization, diversifications, uses. Collection du Centre Jean Bérard, 48. Publications du Centre Jean Bérard, Naples. doi:https://doi.org/10.4000/books.pcjb.2107 